\title{
BRITISH ATTITUDE TOWARDS THE ALLIANCE PARTY, 1952-1957
}

\author{
Joseph M. Fernando
}

The Alliance's Party relationship with the British colonial administration has not received adequate examination in the historical scholarship on Malaysia. Most studies on post-war Malaysian history discuss the Alliance as part of broader political themes such as nationalism, constitutional developments and communal politics. ${ }^{1}$ This is despite the leading role played by this nationalist movement in Malaya's path to independence. Some of the works that refer to the Alliance suggest a collaborative relationship between the British colonial administration and the Alliance Party. Some scholars infer that the Alliance was the recipient of British political patronage. Stenson, for example, notes that because the British 'continued to favour more conservative sections, the Alliance was enabled to acquire the mantle of aggressive nationalism and the compelling slogan of Merdeka.' ${ }^{2}$ Others hint at a kind of collusion between the Alliance leaders and the British administration. ${ }^{3}$ James P. Ongkili contends that one of the reasons for the success of the Alliance in the federal

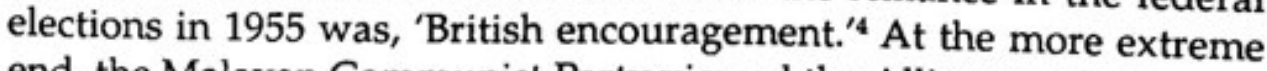
end, the Malayan Communist Party viewed the Alliance as lackeys or 'running dogs' of the British imperialism. ${ }^{5}$ Some works argue that British patronage of the Alliance allowed the nationalist movement to grow in strength and become the leading nationalist movement in 
the 1950s. The lack of an aggressive or violent confrontation against British colonial rule by the Alliance unlike the Independence struggle of the nationalist movement in Indonesia is sometimes cited as evidence.

This essay examines the relationship between the Alliance and the British colonial administration to reconsider some of these interpretations and arguments in the light of the availability of more information from declassified Colonial Office documents and other primary sources in recent years. It is organised in the following way. The first part of the essay examines British attitude and response to the ad-hoc pact between the UMNO and MCA in the 1952 Kuala Lumpur municipal elections which marked the beginning of this cooperative endeavour between two communal organisations. The next section considers the British attitude towards the Alliance as the coalition evolved into the leading nationalist movement between late 1952 and 1954. The following section will then examine British attitude towards the Alliance and its leaders in the period leading up to the first federal elections in July 1955. After the coalition's 1955 federal elections' victory the British administration was largely resigned to working with the Alliance to ensure a smooth transfer of power simply because the party represented the popular will of the people, but not without a last-ditch attempt at the London talks in January 1956 to delay full independence. This essay will argue that the British colonial administration's attitude towards the Alliance was quite antagonistic. The administration was not in favour of the type of inter-communal politics that the Alliance represented, preferring the emergence of a centre non-communal party which could unite all the races. They continued to rely on Dato Onn Jaafar to lead such a movement right up till the 1955 federal elections. Contrary to some interpretations, the Alliance's relationship with the British colonial administration was hardly collusive or cosy. Rather, it had all the ingredients of an adversarial relationship and the Alliance's was hardly considered a suitable partner in the British attempt at nation-building. In this sense, this essay challenges some of the existing interpretations of the Alliance's relationship with the British administration.

\section{British attitude towards UMNO-MCA electoral pact}

British attitude towards nationalist movements in the post-war period Their post-war a mixture of suspicion, toleration and anticipation. after regaining control did not envisage relinquishing power quickly 
They were more preoccupied with consolidating their position and strengthening their economic foothold. ${ }^{7}$ Malaya was an important dollar earner for post-war reconstruction of Britain. Stockwell, for example, notes that British post-war plans was a 'fresh departure designed to consolidate the administration of the British territories, facilitate their economic development and eventually transform the "plural societies" of the "Malayan" region into a self-governing region. ${ }^{8}$ In their minds, self-government and independence was a distant goal for Malaya. The British felt that there was a need to cultivate a sense of Malayan consciousness among the different racial groups in Malaya before it would be ready to take on the responsibility of self-governance. This attitude is clear from the statements of senior administrators from time to time. W.L. Blythe, a former Secretary for Chinese Affairs, writing in March 1948, for example, noted: 'It seems clear that no such thing as an independent Malaya, standing on its own feet without British support, can emerge in the near future. ${ }^{\prime 9}$ The British Commissioner-General for Southeast Asia Malcolm MacDonald felt that a transition period of 25 years was required before Malaya would be ready for complete self-government. ${ }^{10}$

Nevertheless, the British government intended to move Malaya on the road to self-government when the circumstances were deemed appropriate. An indication of this is clear in the preamble to the 1948 Federation of Malaya Agreement which provided for the introduction of elections in Malaya, 'as soon as circumstances and local conditions permit, ${ }^{\prime 11}$ to replace the nominated federal and state legislative councils. Sir Henry Gurney, who replaced Edwards Gent in 1948, in fact worked out a schedule of elections to be held progressively, beginning from town and municipal elections in 1951 and moving later to state elections. Political devolution to local elites, however, was to be a gradual exercise. ${ }^{12}$ At this stage, the British relied largely on Dato Onn Jaafar, the pre-eminent Malay leader of the time and UMNO president, to ensure a greater measure of acceptance of their policies among the local polity, and especially among the Malays. He was viewed by the British Commissioner-General for Southeast Asia Malcolm MacDonald as 'the accepted leader of the Malays, in a position to make his views prevail with them' and ensure their loyalty to the British connection. ${ }^{13}$ When Onn decided to leave UMNO in 1951 after the party refused to open its membership to non-Malays, the British were shocked and tried to talk him out of it. Gurney's record of a discussion with Onn about the latter's decision to leave UMNO indicates the administration's great reliance on Onn for the successful implementation of its policies. ${ }^{14}$ Gurney asked Onn if it was not 
possible for him to continue to lead UMNO and the IMP. Onn, however, indicated that he was frustrated with the sabotaging of his efforts by some party officials. Onn felt that there was a need to free himself of the 'inactive and purely conservative elements in UMNO' who had been obstructing his efforts, including opening the membership of UMNO to non-Malays. ${ }^{15}$ Onn told Gurney that he was confident of taking the live and active elements UMNO and also the kampong Malays' and felt that the party would not recover from this. Onn anticipated that UMNO would then breakdown in purely state organisations and eventually disintegrate. ${ }^{16}$ In the discussion mentioned above they also talked about how the IMP might secure seats in the Legislative Council. As Gurney recorded: 'We then went on to discuss how the IMP might secure seats in the Legislative Council, a point which I raised myself because the UMNO nominees have recently been put in for three years. I said I hoped we could come to an understanding within the constitution whereby the majority of the unofficial seats could in effect be held by parties, rather then adhering to the rather vague understandings which we are at present. ${ }^{17}$ The Gurney administration was clearly paving the way for IMP officials to be appointed to the Legislative Council. Interestingly, Gurney did not think highly about the newly-elected UMNO president Tunku Abdul Rahman. Following a talk with the Tunku after his election on 25 August 1951, Gurney remarked: 'I am afraid that he will not be the sort of leader who will be capable of holding UMNO together in any important controversy. He will not of course be persona grata to the Rulers, and sooner or later these differences will have to be faced. ${ }^{18}$

Onn's statements and political stand on many issues were Malaya at the the administration and had far reaching implications for on 13 June 1951 . ${ }^{19}$ When Onn, for example, made a press statement within seven years, this annoyed would be ready for independence the European business annoyed not only the administration but also Gurney to ask if Onn's statemunity which sent a delegation to meet Onn clarified that the press statent represented government policy. ${ }^{20}$ it for fear of confusing the situationt was incorrect but did not retract Onn would be able to lead the non-communal The British hoped that away from communal politic non-communal party and move Malaya '... I have never made antics. As Gurney wrote to the Colonial Office: would be a move in the any secret of the view that a united party politics. ${ }^{21}$ 
Events in Malaya, however, took a different turn with the introduction of local elections. UMNO and the MCA reached an agreement to cooperate in the Kuala Lumpur Municipal elections. The ad-hoc pact between UMNO and the MCA which emerged a few weeks before the 15 February 1952 Kuala Lumpur Municipal elections was treated with much suspicion and cynicism by the British administration. It was viewed as a 'marriage of convenience.' At the time, the IMP had the implicit support of the British administration and was expected to win the election comfortably. The UMNO and MCA pact was viewed by the administration to contain inherent irreconcilable differences, and unfavourable in terms of Malaya's political development. The new High Commissioner Sir Gerald Templer's first discussion on Malaya's political progress following the Kuala Lumpur elections was not with the Alliance which won nine of the 12 seats, but with IMP leaders such as Onn and E. Thuraisingham. ${ }^{22}$ The administration was at that stage still banking on Onn's IMP in the local elections.

Even after the big win at the Kuala Lumpur elections the British did not anticipate that the UMNO-MCA Alliance would last long and observed with much pessimism the roundtable discussions held between the UMNO and the MCA to reach agreement on intercommunal issues and to expand their cooperation to other local elections in late 1952. A minute of Colonial Office, for example, noted in November 1952: 'As our policy is to build a "united Malayan nation," we cannot endorse the communal motives of either group [UMNO and MCA]. Yet the Independence of Malaya Party, standing in the middle and professing to be non-communal, shows every sign of being on its last legs, its leadership divided and its following nonexistent. ${ }^{23}$ The British policy towards Malayan political parties is also evident from Templer's discussion with Colonial Office officials in London in December 1952. At this meeting Templer remarked that Malaya lacked political leaders and 'there were no political parties of the type required to operate successfully a parliamentary system. ${ }^{24}$ Heng Pek Koon notes that although the IMP was soundly defeated in the Kuala Lumpur elections, Onn continued to have the ear of the colonial administration as they wanted the IMP to succeed as the country's first multiracial party. ${ }^{25}$ The administration nominated more IMP officials than UMNO-MCA representatives to the Federal Legislative Council.

Nevertheless, following the Alliance's nationwide success in the local elections, Templer moved to recognise the coalition as an important emerging political power, offering two Member portfolios (equivalent to a Cabinet post) to the Alliance. This was to an extent 
influenced by the position of the Colonial Office which in late 1952 urged the administration to recognise the strength and influence of the Alliance among the population. There was also a fear that the UMNO-MCA coalition might otherwise be in complete opposition to the administration. Templer in a letter to the Secretary of State Oliver Lyttelton dated 28 September 1953 noted the Alliance 'has shown its strength in the country by winning seats at local elections as far apart as Alor Star and Seremban,' and proposed that that one member each from UMNO and MCA be appointed as Members of government. ${ }^{26}$ He nevertheless obtained the agreement of Dato Onn before making the offer to the Alliance. Wrote Templer: 'As these proposals might have produced serious reaction among the IMP Committee of the National Congress Group, I discussed them with him Onn before approaching any member of the Alliance, and he expressed himself as completely in agreement. ${ }^{27}$

Two Alliance members, H.S. Lee and Dr Ismail Abdul Rahman, were subsequently co-opted in the Federal Council. But this was really only a small concession. There was in fact an ongoing attempt to breakup the new movement. The British administration was in fact plotting the defeat of the Alliance together with the IMP leaders. The first attempt was to get all the parties to merge under a new party ${ }^{28}$ The Alliance leader Tunku Abdul Rahman declined to be involved in this process. This proved unsuccessful as the parties had grown far apart following the local elections and were not receptive to the idea. When the Alliance announced plans to call for a national convention to discuss the question of self government, the pro-IMP 'Moderates' quickly announced their own plan to hold a national conference on 27 April 1953 to discuss the question of self-government. The Alliance boycotted this conference. The Tunku said that the conference was not representative of the people: 'The UMNO and the MCA hereby state that they do not believe that the proposed conference as constituted will be able to reflect the true wishes of the people of this country and cannot thereby have sufficient authority, as recognised under democratic principles, to lay down proper steps that should be taken to build a united, self-governing Malayan nation. ${ }^{29}$ The British administration then supported the formation of a new non-communal party to replace the failed IMP which was to be led by Onn at a later stage. Discussions on this were held between late October 1952 and March 1953 and it involved the Commissioner-General for Southeast Asia Malcolm MacDonald and High Commissioner Sir Gerald Negara in 1954 . There was later to emerge in the form of Party 
check the growing influence of the Alliance, including efforts to ban communal parties from taking part in elections. ${ }^{31}$

In this period then we see a tussle between the British-backed pro-IMP 'Moderates' led by Onn and the UMNO-MCA alliance. With increasingly vocal calls from the Alliance to speed up the process of devolution of political power, the Templer administration now tried to steal the initiative from the political parties by forming an elections committee in 1953 to discuss the question of federal elections. The administration was anxious to ensure that it did not place itself in a position where 'nationalist pressure would be seen to have made the administration speed up the process of political advancement.. ${ }^{\prime 32}$ The majority in this committee were pro-IMP leaders who preferred a more gradual approach to self-government and the Alliance's views for an elected majority and holding of elections in 1954 were largely submerged, forcing it to issue a minority report stating its own views. The recommendations of this committee with slight modifications made by Templer to allow for a small elected majority were forwarded to the Rulers and the Colonial Office for approval. The Alliance's own National Convention which was held in August 1953 recommended a small majority, 60 per cent of elected seats and for the elections to be held in $1954 .{ }^{33}$ The Templer administration, as we will see below, refused to entertain the Alliance's recommendations, forcing the coalition to take their case to London before the Secretary of State.

\section{Alliance federal election plan and British reaction}

The uneasy and sometimes adversarial relationship between the Alliance and the British colonial administration is also evident in the period of the coalition's concerted agitation for the introduction of federal elections. The Alliance leaders were concerned for sometime that their victories in the local elections were not reflected in terms of greater political powers in the federal and state councils. These councils were still dominated by IMP leaders and their supporters. The Alliance in these circumstances decided to push for the introduction of federal elections. On 17 March 1953, following a series of meetings between the UMNO and MCA leaders, the Alliance announced that the parties had reached agreement on federal elections and planned to hold a national convention. ${ }^{34}$ The UMNO and MCA boycotted an alternative conference convened by pro-IMP chief ministers on 27 April 1953, and in their own 23 August 1953 convention demanded that federal elections be held in 1954 and that three-fifths of the members of the 
federal legislature be elected. In the opening speech at the convention, the Tunku noted:

The people feel that it is time that they are given bigger roles to play in the political affairs of the country ... I believe that Independence of Malaya can only be brought about by constitutional changes and such constitutional changes can only be affected by a change in the Federal Legislature. There is no option left for us but to demand for an early election. ${ }^{35}$

The Templer government and the Colonial Office were at first uncompromising on the Alliance's demand to hold federal elections in 1954 and for a three-fifths majority of elected members in the legislature. While the Alliance leaders had a cordial working relationship with the Templer, he was not initially willing to budge from the recommendations of his all-party elections committee set up in July 1953 and which proposed a minority of 44 out of 92 elected members in the new federal legislature. He attempted to talk the Alliance out of pursuing seriously their threat of a boycott of cooperation with the federal government. In the event, Templer recommended to the Conference of Rulers a small majority which was eventually agreed at 52 elected members out of a total of 98 on 27 March $1954 .^{36}$ The Alliance, however, felt that this did not meet their demand for a three-fifths majority and decided to take their appeal to the Secretary of State in London. In their petition to the Secretary of State the Alliance sought to justify their demand:

A three-fifths majority is the minimum based on the necessity of providing a sufficient majority of elected seats if the party or parties, who command the majority amongst the electors, are to have a sufficiently effective voice in the Council of Government, bearing in mind that they are unlikely to be able to command all the elected seats. ${ }^{37}$

Even as the Alliance delegation was in London discussing the issue with the Secretary of State, the Templer administration was advising the Colonial Office to refuse the Alliance's demands for a sixty per cent majority of elected seats in the federal legislature and the holding of federal elections in 1954. ${ }^{38}$ The official records of the discussions relating to the federal elections certainly indicate no evidence of any cosy or collusive relationship between the Alliance and the British colonial administration. If anything, the parties were poles apart on the major political issues and especially on the devolution of political power and movement towards self-government. The Secretary of State 
at first flatly refused to meet the delegation but obliged following the intervention of Lord Ogmore. ${ }^{39}$ The Secretary of State Oliver Lyttelton's cynical observation of the Alliance leaders following their meeting in London on 14 May 1954 reflects the wide differences between them: 'My impression of the delegation is that they are three worried little men [referring to Tunku Abdul Rahman, Abdul Razak and T.H. Tan] and on evidence of their attitude when with me I should doubt whether they will in fact press their opposition to the present proposals by the extreme measures which they have threatened. ${ }^{40}$

Even at this stage while the British administration was willing to move a little on the Alliance's demands following intervention by Lord Ogmore and several Labour party members, they refused to meet the Alliance's demands fully. In his letter to the Alliance, Secretary of State wrote:

... there is between us no essential disagreements upon principle and little even upon practical issues ... there is no difference between us in our anxiety that the first Federal elections should be held as soon as possible; it is a practical impossibility to hold them before the end of this year but they will be held as early as possible next year ... above all, your desire that the majority party in the Legislative Council should be able to function effectively in government will be fully satisfied by my assurance that, if it were prevented from doing so by deliberate obstructiveness, I should at once ask the High Commissioner to consider with the Conference of Rulers how the situation should be remedied ...4

This is hardly the type of reaction one would expect if the two parties were working hand-in-glove. The Secretary of State was clearly elusive in his response and while conceding that elections would be held in 1955, was not willing to make further concessions to the Alliance.

Undeterred by the Secretary of State's response to their demands, the Alliance decided to take more aggressive direct action to back up their demands. They decided to go ahead with their threatened boycott. In fact, the Alliance leaders took a secret oath after their return to Malaya from London indicating their willingness to go to prison if their boycott action led to their arrests. In a special meeting of the Alliance leaders on 31 May 1954, the Tunku said: 'Our withdrawal [from their official posts] may mean trouble, maybe serious trouble, for some of us. I am prepared to go to gaol if necessary to achieve our aims. How many of you are prepared to do the same?'12 The other leaders were unanimous in their readiness to go to prison. 
There was more drama in Malaya when the Alliance delegation decided to go-ahead with their boycott action. The new High Commissioner Sir Donald MacGillivray at first refused to accede to the Alliance's demands and advised the Colonial Office accordingly. MacGillivray, writing to the Secretary of State on 2 June 1954, urged a tough line: 'I feel that the Alliance will recognise the weakness in their position once they realise that we are prepared to stand firm ... and to go ahead with our plan for Federal elections. ${ }^{.43}$ It was only when the Alliance implemented their boycott action and organised large-scale demonstrations and when the potential for a breakdown of law and order seemed inevitable, Malaya being in the middle of an on-going insurgency, that MacGillivray made some concessions. In a meeting with the Alliance leader Tunku, he offered the five reserved seats (usually decided by the High Commissioner) to be decided by the winning majority party. ${ }^{44}$ This was a significant move as it amounted to the political parties being able to decide almost sixty percent of the seats. This broke the deadlock but the Alliance still had an uphill task in the federal elections as the British covertly support Party Negara.

\section{Banking on Onn and Party Negara}

The British administration was hoping that Onn's Party Negara which replaced the defunct IMP would be able to secure at least 30 percent of the elected seats in the first federal elections in July 1955 and in that way prevent the Alliance from forming the government. This, they believed, could also diminish the momentum of the Alliance's push for speedier movement towards self movement. The Alliance was expected to win between 30 and 45 seats. ${ }^{45}$ One director of a British company, Sir Sydney Palmer, for example, expressed confidence that Party Negara was 'the party of the future,' and when the elections were held in 1955 'would be the successful party. ${ }^{46}$ This would mean that there would be no clear majority among the parties and reduce nationalist pressure on the colonial administration. Several moves were made, sometimes with covert support from the colonial administration, to disrupt the Alliance's electoral preparations and to diminish its proportion of issues popular with voters, in particular focused on championing language to unsettle Malay community such as immigration and Malayan Indian Congre coalition which had now been joined by the before the federal the Federal Legislative Cons, Party Negara introduced a resolution in 
of the federation. The Tunku felt that the introduction was intended to break-up the Alliance: 'This motion has been introduced with the aim of breaking racial unity. These people and their party [Party Negara] are making efforts to break up the Alliance because of their failure to win a single seat ... Malay is and will be the national language when the time comes. ${ }^{18}$ His colleague Sardon bin Haji Jubir added that UMNO supported Malay as the national language but felt that only when the country was independent could it be made so. ${ }^{49}$

The Alliance bold election objectives were hardly of any comfort to the British. The Tunku said the Alliance wanted Independence in four years after the July elections and a fully elected Federal Legislative Council by the following term. ${ }^{50}$ In the state of Selangor, an Alliance councillor Ong Yoke Lin, describing the Selangor State Council as 'partly feudal and partly colonial,' made an unsuccessful appeal for an elected majority. The State Secretary Abdul Aziz bin Haji Abdul Majid in opposing Ong's motion argued that a select committee had studied the issue and recommended an elected minority and that the motion 'would undo all the work which had been carried out and would further delay the elections. ${ }^{51}$ In the election campaign, the Alliance was quite blunt in its criticisms of the British colonial administration. The Tunku attacked what he termed 'the policy of the imperial masters to divide the people of the country and perpetuate colonialism,' adding that the Alliance saw through this and broke down the barriers that divided the Malayan communities. ${ }^{52} \mathrm{He}$ criticised the 'blue-eyed boys, found among senior Malay officers,' who he said were obstructing the Alliance's campaign for independence. ${ }^{53}$ The Alliance described the federal election as only 'half-way democracy.' ${ }^{54}$ The Alliance, the Tunku said, will not rest until full democracy was given to the people.

The British administration was shocked by the results of the federal elections. While the Alliance was expected to $\mathrm{win}^{55}$, the margin of victory, wherein the party won 51 of the 52 seats, was most unexpected. Historian C.M. Turnbull, then working as an administrative officer in Malaya and returning to Kuala Lumpur after standing in as a polling officer in Kota Bharu, reflecting later on the elections, noted: 'We landed in Kuala Lumpur to yet another shock, to find nearly the whole country had put their cross beside the Alliance ship. ${ }^{56}$ But the Alliance still had an uphill task in realising its goal of independence. The Tunku was in fact quite poorly treated even after being elected the Chief Minister. He was given a quarters with a leaking roof, hardly befitting his position. ${ }^{57}$ This only increased his resolve and he decided to push for a quicker transfer of power from the four years pledged by the Alliance in the election campaign. 
After the emphatic July 1955 election victory, the Tunku in his first meeting with the Secretary of State Alan Lennox-Boyd in August reiterated the need to grant Malaya independence in the shortest possible time and also the need to revise the constitution. ${ }^{58}$ The Tunku also suggested that the veto powers of the High Commissioner and the position of British Advisers should be abolished. But LennoxBoyd was non-committal, suggesting the need for further discussions to be held on a wide range of issues relating to Malaya's internal and external defence, financial autonomy, among others. He chided the Alliance a day after this meeting on its 'unduly constant preoccupation with constitutional change. ${ }^{\prime 59}$ The British administration was in fact thinking of the more modest goal of internal self-government following the Alliance victory in the federal elections rather than full self-government or independence. Lennox-Boyd invited the Tunku to discuss these issues in London in early 1956. Interestingly, even at the London Conference of January-February 1956, the Colonial Office was still not convinced that Malaya should be accorded independence in 1957 as demanded now by the Alliance. This is evident from the internal deliberations of the Colonial Office on the terms of reference for the Reid Commission before the conference. A memorandum on the Commission's terms of reference, for example, noted: '.. we should hope to obtain their agreement to the more modest proposal that the terms of reference of the commission should be so drawn up as to set it the task of preparing a scheme only for internal selfgovernment, excluding defence and foreign affairs. ${ }^{\prime 60}$ The Alliance electoral victory hence did not mean an automatic grant of independence. There was a shift in the British position only as the conference began and it soon became clear that the Alliance was strongly committed to its target date of 31 August 1957 as the date of independence. Following assurances that British economic interests in Malaya would be safeguarded after independence, the British government agreed to the grant of independence. ${ }^{61}$

\section{Conclusion}

The discussion above shows that the Alliance had an uneasy and at Right from the inception of the the British colonial administration. unsettle the pact. The British adminition in 1952 there were efforts to and later the Party Negara. They wintration backed the Onn-led IMP the type of communal politics rere clearly uncomfortable with preferred a non-communal alics represented by the Alliance. They 
communal party would emerge in Malaya. In the circumstances, this did not materialise. After the first federal elections in 1955 the British were reconciled to the fact that the Alliance represented the best opportunity in ensuring a smooth transfer of power. The Alliance approach was firm but not aggressively confrontational. The coalition had decided to struggle for independence within the constitutional framework. They eschewed the violent and aggressive campaign taken by nationalist movements in many other parts of Asia an Africa. It was a conscious decision. This to an extent contributed to the coalition being sometimes regarded as colluding with the colonial administration. In reality, this was hardly the case. The Alliance pushed the colonial administration aggressively on the issue of federal elections in 1954 and their effort was a crucial turning point in the decolonisation process. They forced the British to set a definite timetable for the holding of federal elections and subsequently the grant of independence. If the Alliance was colluding with the British colonial administration, they would not have embarked on such a hazardous campaign for federal elections. As Tim Harper rightfully noted, 'as partners in nation-building they [the Alliance] were not the allies the British would have chosen. ${ }^{62}$ The Alliance essentially was a moderate anti-colonial nationalist movement that campaigned for independence within the framework of the constitution. 


\section{Notes}

1 See, for example, Heng Pek Koon, Chinese Politics in Malaysia, Singapore: Oxford University Press, 1988; Karv Von Vorys, Democracy Without Consensus, Princeton: Princeton University Press, 1975; Khong Kim Hoong, Merdeka, Petaling Jaya: SIRD, 1984; and Mohamed Nordin Sopiee, From Malayan Union to Singapore Separation, Kuala Lumpur: University of Malaya Press, 1974. Michael Stenson, Class, Race and Colonialism in West Malaysia, St Lucia, Queensland: University of Queensland, 1980.

See for example, Ramlah Adam, Tunku Abdul Rahman, Kuala Lumpur: Dewan Bahasa dan Pustaka, 2004, p. 180.

4 James P. Ongkili, 'The British and Malayan Nationalism, 1946-1957, Journal of Southeast Asian Studies, Vol. 5, No. 2, 1974, p. 269.

Karl Hack, Defence and Decolonisation in Southeast Asia, London: Curzon, 2001, p. 139. Tunku Abdul Rahman, for example, told the British that he should be allowed speak freely at the Baling talks in December 1955 with the MCP leaders and not as a 'running dog,' a term often used by MCP to refer to the Alliance leaders. Minute by Colonial Office Committee on Post-war Problems (CPWP), 2 April 1942, CO 825/35/4. Nicholas J. White, Decolonisation, London: Longman, 1999, p. 1. White notes that after the Second World War, Africa and Southeast Asia took on new significance for imperial economic and military strategy.' A.J. Stockwell, Malaya, Series B, Vol. 3, London: HMSO, p. liv. See Note by Blythe, March 1948, CO 537/3746 (9).

10 Minutes of 15th Commissioner-General's Conference, 7 June 1950, CO $537 / 5961$ (25).

11 J. de V. Allen, L.R. Wright and A.J. Stockwell (eds) (1981), A Collection of Treaties and Other Documents, Affecting the States of Malaysia, London: HMSO, Vol. 1, p. 101.

12 Gurney to Paskin, 31 Dec. 1949, CO 537/474 (83).

13 Lloyd to Gurney January 1949, CO 537/3746, cited in A.J. Stockwell, Malaya, Series B, Vol. 3, Part II, London: HMSO, 1995, p. 97.

14 Gurney to Secretary of State, 13 June 1951, CO 537/7303.

Gurney to Higham, 13 June 1951, CO 537/7263 (10).

Gurney to Higham, 13 June 1951, CO 537/7263 (10).

Gurney to Higham, 29 Aug. 1951, CO $537 / 7297$ (18).

Oong Hak Ching, Chinese Politics in Malaya, 1942-55, Bangi: Universiti Kebangsaan Malaysia, 2000.

Gurney to Griffiths, 22 June 1951, CO $537 / 7303$ (12).
Ibid.

Templer to Lyttelton, 12 March 1952, CO 1022/298 (6).

Minute of Colon 4 Nov. 1952, CO 1022/298.

1022/86 (3). 
25 Heng Pek Koon, Chinese Politics in Malaysia, p. 181.

26 Templer to Lyttelton, 28 Sept. 1953, CO1022/86 (66).

27 Ibid.

28 Note by MacGillivray, 6 April 1953, CO1022/86 (5).

${ }_{30}$ UMNO/SG No. 35/53 (1), Arkib Negara Malaysia, Kuala Lumpur.

${ }^{30}$ Note by MacGillivray, 6 April 1953, CO 1022/86 (5).

31 Heng Pek Koon, p. 170-171.

32 MacGillivray to MacDonald, 17 April 1953, CO 1022/86 (23).

UMNO/SG 135/1953. Opening speech by Tunku Abdul Rahman, 23

August 1953.

MacGillivray to MacDonald, 17 April 1953, CO 1022/81 (24).

35 Opening speech by Tunku Abdul Rahman at National Congress, 23 August, 1953, UMNO/SG. No. 35/53.

Templer's memorandum to Conference of Rulers, 25 February 1954, CO 1030/219 (11). See also MacKintosh to Watherston, 23 January 1954, CO 1030/219 (2). (21).

Templer's Memorandum to Conference of Rulers, 25 February 1954, CO 1030/219 (11).

39 Lord Ogmore to Secretary of State, 20 April 1954, CO 537/309 (20).

40 Lyttelton to Templer, 15 May 1954, CO 1030/309 (53).

41 Lyttelton to Tunku Abdul Rahman, CO 1030/310 (56), 18 May 1954.

42 Harry Miller, Prince and Premier, New York: Frederick Praeger, 1959, p. 145.

43 MacGillivray to Secretary of State, 2 June 1954, CO 1030/310 (80).

44 MacGillivray to Secretary of State, 3 July 1954, CO 1030/310 (125).

$45 \quad$ Straits Times, 27 July 1955.

46 Nick White, Business, Government and The End of Empire,' Kuala Lumpur: Oxford University Press, 1996, p.142.

47 G.P. Means, Malaysian Politics, London: Hodder and Stoughton, 1976, p. $158-160$.

48 Straits Times, 1 April 1955.

49 Ibid.

so Straits Times, 12 April 1955.

51 Straits Times, 20 April 1955.

$52 \quad$ Straits Times, 4 July 1955.

53 lbid.

54 Straits Times, 5 July 1955.

55 Straits Times, 27 July 1955.

56 C.M. Turnbull, 'The Post-War Decade in Malaya: The Settling Dust of Political Controversy,' JMBRAS, Vol. 60, Part I, 1987, p. 22.

57 Patrick Keith, Ousted, Singapore: Media Masters, 2005, pp. 13-15.

58 Tunku to Lennox-Boyd, 22 August 1955, CO 1030/70 (35)

59 Note by MacGillivray of the meeting between Lennox-Boyd and Tunku, 22 August 1955, CO 1030/70 (46) 
Memorandum on Terms of Reference and Composition of Constitutional Commission, January 1956, CO 1030/129 (27).

61

See Minute by MacKintosh, 16 January 1956, CO 1030/70 (84) and CAB 128/30/1, CM 4 (56) 3, 'Malaya': Cabinet conclusions on policy to be pursued at constitutional conference, 17 Jan. 1956, cited in A.J. Stockwell, Malaya, Series B, Vol. 3, London: HMSO, pp. 259-265.

Tim Harper, The End of Empire and the Making of Malaya,' Cambridge: Cambridge University Press, p. 340. 